\title{
Accounting Profession and Ideals of Development: Is there a Nexus?
}

\author{
Nwosu M. Eze \\ Internal Audit, National Institute for Legislative Studies, National Assembly, Abuja - Nigeria
}

\begin{abstract}
As the Nigeria economy develops, corporate organizations become increasingly popular and the number of shareholders also increase in leaps and bounds. The separation of ownership and management has led to a need for authoritative and reliable standards of financial reportingand therefore professionalization of the accounting function and subsequently, the accountancy profession. Therefore, determining the accountancy functions and the role the profession plays in Nigeria's economy becomes inevitable. The paper evaluates the role the accountancy profession plays in fostering the ideals of NEEDS, NEPAD and AGOA in Nigeria. The paper brings together existing knowledge regarding the accountancy profession and its skills while stating them in practical terms. It reveals that lack of the involvement of the Accountancy profession in the business community and government is a major cause that hinders growth and development. The paper recommends among other things the role of the accountancy profession plays in the implementation and realization of the ideals of Nigerian government's NEEDS and similar initiatives (NEPAD AND AGOA).
\end{abstract}

Keywords: Accountancy Profession, Financial Reporting, Ownership and Management, Corporate Organization, NEEDS, NEPAD and AGOA.

\section{Introduction}

In recent times, there has been an ever-increasing tendency of Nigerians to organize and form professional associations. It seems that many Nigerians now want to be described as professionals just as many more want to be chiefs or simply, to have one title or the other which signifies a deliberate effort by Nigerians to avoid being described simply as Mr. and Mrs.

The concept of professional can loosely be defined as an association of people that belong to the same trade or share the same views; such associations (Political Profession), Trade Associations, Trade Unionism, Business Association, Business Profession, Musical Association, etc are seen as "Professional" bodies in Nigeria, perhaps alongside such world-class professions as Law, Engineering Medicine and Accountancy.

Pierson (1959) states that "prior to the late 1800s most enterprises in the United States of America were organized as sole proprietorship and their accounting needs were limited to internal analysis and record keeping desired by the owner-manager".

As the economy developed, the corporate form of organization, became increasingly popular and the number of shareholders also increased in leaps and bounds. By the structure of corporate form of organization, it is extremely impossible for a large number of shareholders to participate actively in the operation of the business in which they have invested. Instead, management was delegated to hire executives who serve as trustees for the owners.

This separation of ownership and management has led to a need for authoritative and reliable standards of Financial Reportingand therefore professionalization of the accounting function and subsequently, the Accounting Profession.

Accountancy has become one of the most popular professions in the world. Every nation of the world has an accountancy body, which sets the standards of practice of the profession in the country.

Accounting profession is a growing profession, which requires its members to regularly adapt to the changing environments of business and the economy. The profession was one of the first to embrace changes in information technology, which members found to be very useful in their practice of profession.

Nigerian Accountants have been called to provide many types of special services other than those of examination of accounting records and reports. These other services include development and modification of organization plans, assistance in the installation of data processing equipment, preparation of capital budgets and forecasts, assisting in management incentives and pension programmes, consulting services and other analyses not ordinarily considered part of the year end audit programme.

Managements have looked up to the accounting firms to provide such services because of their high professional standing in the business community and the government.

The paperattempts to properly identify what a Profession is, Accounting as a Profession, the components of the Profession of Accountancy as a Profession in helping to develop the ideals of some Nigerian government initiatives such as NEEDS and NEPAD. As well as AGOA. 


\subsection{Skills of the Accountancy Profession}

\section{Literature Review}

Among all credible professions, Accountancy Profession stands out clearly as a profession that has tools kit for practicing the profession. We have noted above some of the various professional accountants services, which include (but not restricted to):

a. Examination of accounting records and reports

b. Financial Reporting for ownership (shareholders).

c. Development and modification of organization plans

d. Assistance in the installation of data processing equipment (computers, programmes, etc)

e. Preparation of capital budgets and forecasts

f. Assisting in creating management incentives and pension schemes

g. Management Consultancy, which includes professional advice, feasibility studies and development of training, programmes for client organizations.

In carrying out all the above functions and services, the profession has over the years "invented" various accounting tools used by the practitioners of the profession. A survey of accounting literature has produced a list of such tools majority of which are described as traditional accounting ratios.

The accountancy functions, services and tools all constitute the role the accountancy profession plays in every country's economy. How the accountancy profession can use or apply this role in fostering the ideals, of NEEDS, NEPAD and AGOA in Nigeria is the major thrust of this paper.

\subsection{What is a Profession?}

The Longman Dictionary of Contemporary English ( $3^{\text {rd }}$ ed., 1995) defines a profession as a job that requires special education and training or someone who has a lot of experiences and does something very skillfully. Professionalism is another related concept used in the discussion of profession and it is also defined as the skill and high standards of behaviour expected of a professional person.

Though definitions of a profession are numerous and varied, but most tend to stress the same points. Nevertheless, all the definitions of Profession agree with Mary Parker Follett (1941) that "the word "Profession" connotes a foundation of science and a motive of service" from Follett's definition we can derive clearly what a Profession is. These are:

a. It must be distinctly practiced e.g. Medical Practice, Accounting Practices etc.

b. Its practice must rest on a systematic body of knowledge of substantial intellectual content and on the development of personal and acquired skills the application of this knowledge to specific cases of human endeavour.

c. There must exist standards of professional conduct, which take precedence over the goal of personal gain, governing the professional person's relations with his/her clients and his or her fellow practitioners.

d. A profession has its own association of members among whose functions are the enforcement of standards the advancement and dissemination of knowledge and to some extent, the control of entry into the profession.

e. In every case, there is a prescribed way to entering the profession through the enforcement of minimum standards of training and competence and qualifying examination(s).

\subsection{Five Distinct Criteria of a Profession:}

Clearly, every profession must satisfy these distinct criteria: First every profession must be practiced and practicing members must have their personal offices where they (the practitioners) receive their clients. In other words, the practitioners must have his clientele and his charges are generally in conformity with the charges of all other practitioners of the same profession.

Everybody will agree that in typical Professions like Medicine, Law, Engineering, Architecture and certainly Accountancy practicing members comply with the requirements of this criterion of "being distinctly practiced"The second criterion, the profession practiced must rest on a systematic body of knowledge of substantial intellectual content and the development of personal and acquired skill in the application of this knowledge. This criterion is obviously demonstrated by the fact that every credible profession is recognized by the government of any country where it is practiced and which legally charters it. In its charter, it is clearly stated that the profession must have a body variously described as a body, a council or a board, which regulates how the profession's skill must be acquired, used and continuously improved through organized retraining processes.

Criterion three (3) also requires the profession's governing council to determine standards of professional conduct and to monitor member's adherence to the standards and prescribes appropriate punishment for non-compliance among members. To achieve this objective, the professions' board establishes a 
Disciplinary Committee or its equivalence, which has the responsibility to try deviants, prescribe the appropriate sanctions and monitors compliance to the sanction. I believe the Accountancy Professions in Nigeria adhere to the requirements of this criterion. I believe also that other credible professional bodies in Nigeria e.g. Law and Medicine obviously have governing bodies' councils.

Criterion four (4) states that in addition to prescribing standards of practice for the profession, the professional body must also advance and disseminate knowledge and skills of the profession and in addition control entry into the profession. In complying with the requirements of this criterion, virtually all professions establish and promote a journal or journals, which they employ to advance research in the profession and disseminate both old and new knowledge and skills in the profession. Indeed, some of the most influential journals in the academia are owned by professional bodies and are highly rated and therefore the best intellectuals in the profession compete to get published in these journals.

Prescribing way(s) of entry into the profession is considered one of the most important roles of a profession. Therefore, criterion five (5) is used as a means to enforce minimum standards of training and competence in the profession. To ensure that the best candidates for admission into a professions, its examination board endeavours to strictly monitor its examinations standards in such a way that any candidate that passes their examinations actually merits the pass.

However, for any profession seeking the most effective means of training future potential members, the crucial criterion is indeed the second one: the existence of a systematic body of knowledge of substantial intellectual content and development of personal skill in the conscious application of this knowledge to specific cases. In every sense, the Accountancy profession meets this criterion.

\section{Needs, Nepad, Agoa}

This paper attempts to examine the role of Accounting Profession in Fostering the Ideals of NEEDS, NEPADS \& AGOA, thereis need to understand these acronyms and their purpose in Nigeria.

\subsection{NEEDS: National Economic Empowerment Development Strategy (Governments Economic Reform Programme).}

Nigerian has gone through many years of military dictatorship and massive economic plunder which resulted in a tremendous political, social and economic decay of the Nigerian society. Prior to the democratic transition in 1999, poverty was on the increase. The GDP growth rate was very low and poverty was worsening to the extent that in 1996 poverty data suggested that poverty incidence could be as high as $70 \%$ if no concerted effort was made to stem it.

Therefore, the present government became determined to reduce poverty. The National Economic Empowerment and Development Strategy (NEEDS) is the Obasanjo Administration's plan to achieve general economic, social and political development and serious poverty reductions. According to a government publication, NEEDS is Nigeria's homegrown poverty reduction strategy, which builds on earlier two-year effort to produce the interim Poverty Reduction Strategy Programme (PRSP).

The Goals of NEEDS are stated as follows:

a.To create wealth for nation and people of Nigeria

b. To create job and generate more employment

c.Poverty reduction

d.Re-orientation of Nigerian peoples values system.

Indeed, the major thrust of NEEDS is poverty reduction, which seemingly can be achieved through wealth creation, employment generation and value re-orientation which will massively influence dramatic shift in the way and manner Nigerian peoples belief in and perception of the social charter i.e. the responsibility of the governed in their cooperation towards the development and growth and the Nigerian Nation.

The strategies of NEEDS, which it is believed, will lead to realization of the above stated goal include:
3.1.1 Reforming Government and Institution, which consist of Public Sector Reform with a Reform Agenda that includes:
a. Elimination of ghost workers and right sizing of public sector
b. Re-professionalizing the public service
c. Re-structuring and strengthening public sector institutions
d. Privatization of government owned companies
e. Fighting corruption and enforcing transparency in government business
f. Improving efficiency in government expenditure 


\subsubsection{Growing The Private Sector By:}

a. Providing Security and Enforcing Rule of Law

b. Providing Adequate Infrastructure

c. Improving Private Sector Financing

d. Encouraging Sectorial Strategies

e. Privatization and Liberalization

f. Trade and Regional Integration in the West Africa Sub-region and Africa as a whole.

\subsubsection{Social Charter: Human Right Agenda which Include:}

a. Improvement in Health programmes

b. Improvement of Education

c. Working on Integrated Rural Development

d. Provision of Housing

e. Employment Creation and Youth Development

f. Safety Nets

g. Gender and Geopolitical Balance

NEEDS is a Federal Government programme, which is operated at the Federal Government level. At the state level a similar but complimentary programme called State Economic Empowerment and Development Strategy (SEEDS) has been developed also. The NEEDS in collaboration with SEEDS constitute Nigeria's reasoned response to the challenges of underdevelopment. It is expected that a coordinated implementation of both programmes will create at least seven (7) million new jobs during the plan period and as well, reduce poverty and lay the foundation for sustainable development of Nigeria economy.

\subsection{NEPAD: The New Partnership for Africa Development:}

In October, 2001 African leaders produce a document similar to the NEEDS which is titled the New Partnership for Africa's Development (NEPAD) described as a pledge by African leaders "based on a common vision and a firm and shared conviction that they have a pressing duty to eradicate poverty and to place their respective country on a part of sustainable growth and development so as well to be able to participate effectively in the world economic and body politics" include:

NEPAD recognises that the conditions for sustainable development in African nations and continent

a. Peace and Security of lives and property in member countries

b. Democracy and Political Governance

c. Economic and Corporate Governance

The African leaders also recognise in NEPAD, that in other to achieve these three initiatives $(a, b, c$, above) they need to pay serious attention to the following sectoral priorities in their Developmental/National Plans.

3.2.1 Development and Maintenance of Infrastructure

3.2.2 Human Resources Development

3.2.3 Agricultural Development

3.2.4 The Care for the Environment

3.2.5 Serious Attention to Culture

3.2.6 Development of Science and Technology

3.2.7 Mobilization of Human Capital Resource

3.2.8Production of Goods and Creation of Market Access for:

a. Agricultural Produce

b. Mining

c. Manufactures

d. Tourism

e. Services and Services Delivery

3.2.9 Promotion of Private Sector

3.2.10 Promotion of African Export and

3.2.11Removal of Non-Tariff Barriers 


\subsection{AGOA: African Growth and Opportunity Act:}

The aims and objectives of NEPAD were endorsed by the second session of One Hundred and Eight Congress of the United State of America, which passed an act of the congress cited at the AGOA Acceleration Act of 2004 which among other specifications endorsed:

a. Promotion of Market for United States and African Exports

b. Improving Transparency, Good Governance and Political Accountability in African States

c. Expanding access to Social Services, Education and Health Services

d. Promoting the Role of Women in Social and Economic Development

\section{Areas Of Needs (Seeds) Nepad And Agoa Relevant To The PracticeOf Accountancy Profession In Nigeria}

\subsection{The Issue of Transparency:}

Accordingly, the key message of NEEDS is that it is no longer "Business as Usual", hence the privatization programme has been designed to shrink the domain of the state and subsequently the pie of distributable rents which have been the haven of public sector corruption, inefficiency and rent seeking.

One of the professional functions of Accountants is the uncovering of corrupt practices and inefficiency in the management of organizations and also discovering lack of transparency among public office holders.

\subsection{The Issue of Accountability:}

Similar to the Issue of Transparency is the issue of Accountability. The whole gamut of the Accountancy profession is based on the issues of being Accountable and Accountability. Accountability is a process of being accountable by giving a complete account of what the organizational leadership and operators did with the resources made available to them during a particular period of time. Accountability is therefore predicated on the Accountancy functions and profession.

\subsection{The Issues of Professionalism in Civil Service and other Organizations:}

The NEEDS states that the "Public Sector reforms would aim to emphasize Professionalism, selfless service and efficiency (value for money)".This objective is in complete alignment with the practice of the Accountancy profession. The issue of professionalism in the civil service is a re-emphasis of the need for the Accountants, particularly those in the civil service, to be truly professional in the practice of their profession in the civil service and other institutions.

\subsection{The Issue of Access to Information and Public Reporting:}

Without access to information, the governed are denied the opportunity of knowing what public officers are doing and will not be in the position to contribute effectively to governance. Therefore, the Accountant's Public reporting function will be put to tasks with the implementation of NEEDS and NEPAD Programmes. Accounting reports will keep the public informed about the performance of public officers as required by NEEDS and NEPAD programmes.

\subsection{Professional Recording of Transaction in Government:}

Through proper book-keeping of transactions and other ancillary accounting functions, the Accountants, particularly in the public service, will assists government in the effective implementation of the NEEDS and NEPAD programme.

\subsection{The Bill of Rights and Rights to Information Acts:}

These acts can be made effective through professional accounting practices such as proper record keeping of transactions and public reporting.

\subsection{Development of Human Capital:}

Both The NEEDS and NEPAD have extolled the virtues of Human Capital development in solving the problems of underdevelopment. Human capital can be made more efficient and productive through proper training particularly professional training, where necessary and available. The Accounting Profession through the Accounting Body can make their curricula more relevant to the needs of the economy by continuously reviewing their curricula and improving on them with the aim of making them relevant to current economic, industrial and political needs.

\section{Conclusion}

The ideals of NEEDS, NEPAD and AGOA initiatives may be summarized as follows:

a. To create wealth for all the Nations of the African continent. All the above stated initiatives express these ideal. Africa is presently the home of abject poverty and its twin brother, disease. One major strategy of 
reducing poverty and disease is to create wealth, which can be achieved through creation of jobs, investments and industrial development.

b. To ensure peace and security of lives and property in Nigeria and other African countries. Without peace and security, capital flow into African countries will be extremely difficult. Capital inflow is needed for the development of countries in Africa.

c. Reformation of Government (s) and institutions in Nigeria and other African nations, which is a way of ensuring the existence of Democracy and good governance.

d. Improving Transparency and political accountability in Nigeria in particular and other African countries in general. This is a condition that investors from developed countries have always harped on which, if achieved will encourage investment in African countries.

e. Re-orientation of Nigeria and indeed African's value system so as to achieve a shift in their people's belief and perception of the social charter i.e. the responsibility of their government and the people in their cooperative effort to achieve growth and development of thenation's continent.

\title{
VI. Recommendation
}

The paper recommends that there is need for further discussion of these ideals, as it was noted that in order to achieve them, Nigeria and other African countries must address the following critical relevant issues:

\author{
Issues \\ a. Of Transparency. \\ b. Of Accountability. \\ c. Of the need of Professionalism and Professional practices in institutions and organizations in Nigeria and \\ Africa. \\ d. Of Access to Information and publicreporting which are supportive of Accountability. \\ e. Of Professional Recording of Transaction in Government. \\ f. Of Development of Human Capital.
}

It was also noted that these issues pertain to the roles of the Accountancy profession and practice, which include the following (already discussed).

a. Examination of Accounting records and reports

b. Financial Reporting for ownership, clients and stakeholders.

c. Assistance in the development and modifications of organizations plans

d. Assistance in I.T installations and programmes

e. Preparation of capital budgets and forecasts for Government, organizations and industrial establishments.

f. Management consultancy specifically in the areas of professional advice, feasibility studies preparation and professional training for client organizations.

The role of the Accountancy profession in the Implementation and realization of the ideals of Nigerian government's NEEDS (SEEDS) initiative and similar initiative (NEPAD AND AGOA) of the countries of the African continent, indeed, cannot be over emphasized.

\section{References}

[1]. Adegbite, A. (1984) Accounting Ratios and Break Even Analysis, Lagos MurtabEnterprises

[2]. Banwo (1997) "The Fund Flow Statement towards Enhanced Utility", ICAN News, Vol.

[3]. Barton, A.O. (1997) The Anatomy of Accounting, Queensland, University of Queensland Press.

[4]. Banich, L. (1994) Financial Statement Analysis: A New Approach, Eaglewood Cliff.

[5]. Bowen, However R. (1948) "The future of Business Education" in The Challenge of Business Education, Chicago, University of Chicago Press. Pp. 36-44

[6]. Calkins, Roberts D. (1946) “Objectives of Business Education, Harvard Business Review. Pp. 46-47

[7]. Congan, Morris (1955). The Problem of Defining a Profession. The Annuals of American Academy of Political and Social Science, Jan Pp. 105-111

[8]. Gordon, Robort A. And Howell James E. (1959). Higher Education for Business, New York Columbia University Press.

[9]. Hekimian, J.S. \& Jones, C.H. (1967) "Put People on your Balance Sheet" Harvard Business Review, Jan- Feb., pp.88-96. International Accounting Standards Committee 1987, 1994,2005.

[10]. Kaveri, V.S. (1980) Financial Ratios as Predictors of Borrower's Health.

[11]. Longman: Dictionary of Contemporary English Harlow. England, Longman House Burnt Hill Publications.

[12]. Lucey, T. (1996) Management Accounting, 4th edition, Hampshire DPP publishers.

[13]. Metcalf, H.C (1927) Ed. Business Management asa Profession.

[14]. Metcalf, H.C. And L.F. Urwick Ed. (1941). Dynamic Administration- The Collected Papers of Mary Parker Follett, Bath: Management Publications Trust.

[15]. NEPAD (2001).The New Partnership for Africa's Development: NEPAD, October 2001.

[16]. Nigeria - NEEDS (2004). National Economic Empowerment and Development Strategy. The NEEDS Secretariat, National Planning Commission, Federal Secretariat Abuja.

[17]. Nwosu, M. E. (2013) Principles of Accounting with Questions and Suggested Solutions, Petra Digital Press, Abuja-Nigeria. 
[18]. Oando Petroleum Pic (2005) Annual Report and Accounts

[19]. Onaleye, L.A. (1998) Striving for Precision, the Nigerian Accountancy (Vol. 31)

[20]. Pierson, Frank C. (1959). The Education of American Businessmen, New York McGraw-Hill Book Company, Inc.

[21]. The AGOA (2004). The Acceleration and Opportunity Act of 2004. At the One Hundred Eight Congress of the United States of America. At the Second Session. AGOA: Africa Growth and Opportunity Act.

[22]. Yamusa, D. (2000) Financial Management, Lagos DPP Publishers.

[23]. Yusuf, B.R. (2003) Management Accounting in Focus, Lagos Rakson. 